\title{
Dufourmentel Rhomboid Flap for Sacrococcygeal Pilonidal Sinus. Technical Details
}

\author{
Técnica Quirúrgica del Colgajo de Dufourmentel para el \\ Tratamiento de la Enfermedad Pilonidal Sacro-Coccígea.
}

\author{
Carlos Manterola*,**,***; Tamara Otzen ${ }^{* * * * * * * *} \&$ The MINCIR Group.
}

MANTEROLA, C.; OTZEN, T. \& THE MINCIR GROUP. Dufourmentel rhomboid flap for sacrococcygeal pilonidal sinus. Technical details. Int. J. Morphol., 34(4):1207-1210, 2016.

SUMMARY: Sacrococcygeal pilonidal disease (SPD) is a chronic an uncommon entity with a variety of alternatives for treatment. One of those is the excision of the sinus tract followed by a reconstruction with the rhomboid flap described by Dufourmentel. The aim of this paper is to describe the main phases of the technique. A detailed explanation of the key steps for the implementation of Dufourmentel flap for the treatment of SPD is exposed. Excision of sacrococcygeal pilonidal sinus followed by Dufourmentel rhomboid flap is an alternative to consider in the treatment of pilonidal disease.

KEY WORDS: Pilonidal Sinus; Pilonidal Sinus/surgery; Pilonidal Sinus/therapy; Dufourmentel flap; Rhomboid flap.

\section{INTRODUCTION}

Pilonidal disease is a clinical entity characterized by the presence of sinus that generally develops in the hair follicles of the natal cleft of the sacrococcygeal region. Affect principally male young adults of working age. Frequently appears as an abscess or a chronically discharging, painful sinus tract, which is associated with morbidity, often with a prolonged loss of normal activity (Manterola et al., 1991; Sondenaa et al., 1995).

The best treatment would be a rapid cure that allowed patients to return quickly to their habitual activities, with minimum morbidity and a small risk of complications (Sondenaa et al.).

Surgical treatment of chronic pilonidal disease is based on excise of sinus tract, entire healing of the covering skin, and avoidance of relapse. Wound management may be left to restore by open healing or secondary intention diminishing wound tension, which helps difficulties of free healing without relapse if all sinus are completely removed. On the other hand, wound could be closed by primary intention, applying a different technical options (McCallum et al., 2008; Al-Khamis et al., 2010; Enriquez-Navascues et al., 2014).
In this article one of the alternatives to remove and primary repair of sacrococcygeal pilonidal sinus called Dufourmentel's technique (described by Claude Dufourmentel in 1962) (Manterola et al.; Yabanoglu et al., 2014), a modification of the Limberg rhomboid flap (described by Alexander Limberg and published in 1963) (Aydin et al., 2011; Horwood et al., 2012), will be exposed and discussed (Fig. 1).
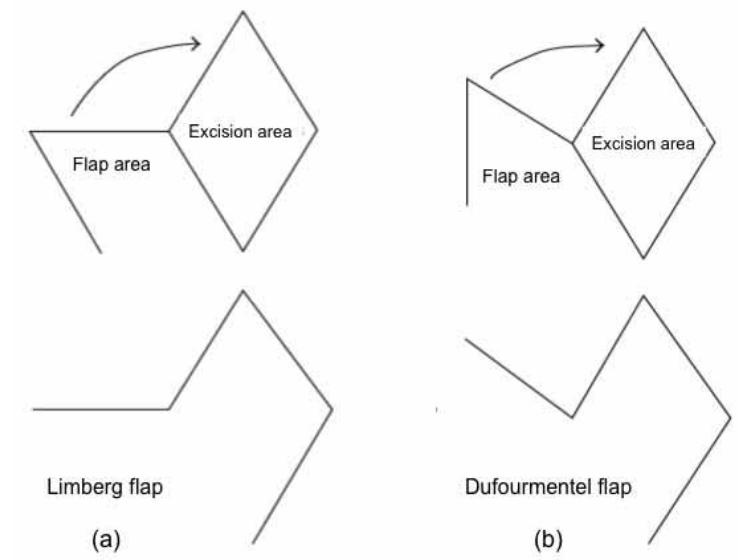

Fig. 1. Mapping schemes for the Limberg (a) and the Dufourmentel flaps.

* Department of Surgery and CEMyQ, Universidad de La Frontera, Temuco, Chile.

* Center for Biomedical Research, Universidad de Autónoma, Temuco, Chile.

**** Ph.D. Program in Medical Sciences, Universidad de La Frontera, Temuco, Chile.

***** Universidad de Tarapacá, Arica, Chile. 


\section{OPERATIVE TECHNIQUE}

Excision of sinus tract: Once separated the buttocks, a rhombus is drawn up in the gluteal region, covering all the visible lesions, descending as far as the presacral fascia (Fig. 2), until completely remove the rhombus (Fig. 3).

Flap design: A diagonal line bisecting the $120^{\circ}$ angle was elongated outside the defect on neighboring tissue with the same length as the diagonal. Next, on the basis of skin laxity around the defect, a donor area that could be closed primarily

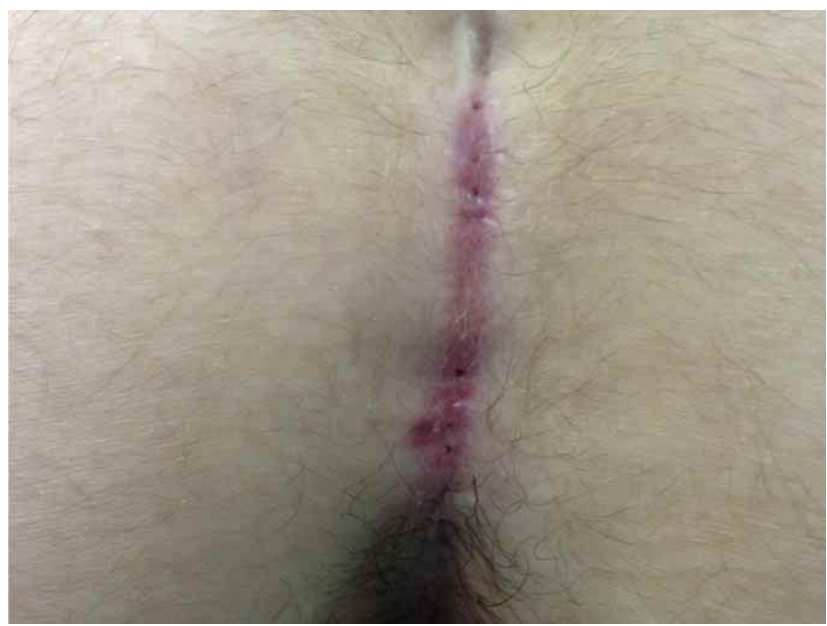

Fig. 2. Sacrococcygeal region. Several sinuses in the midline raphe can be seen.

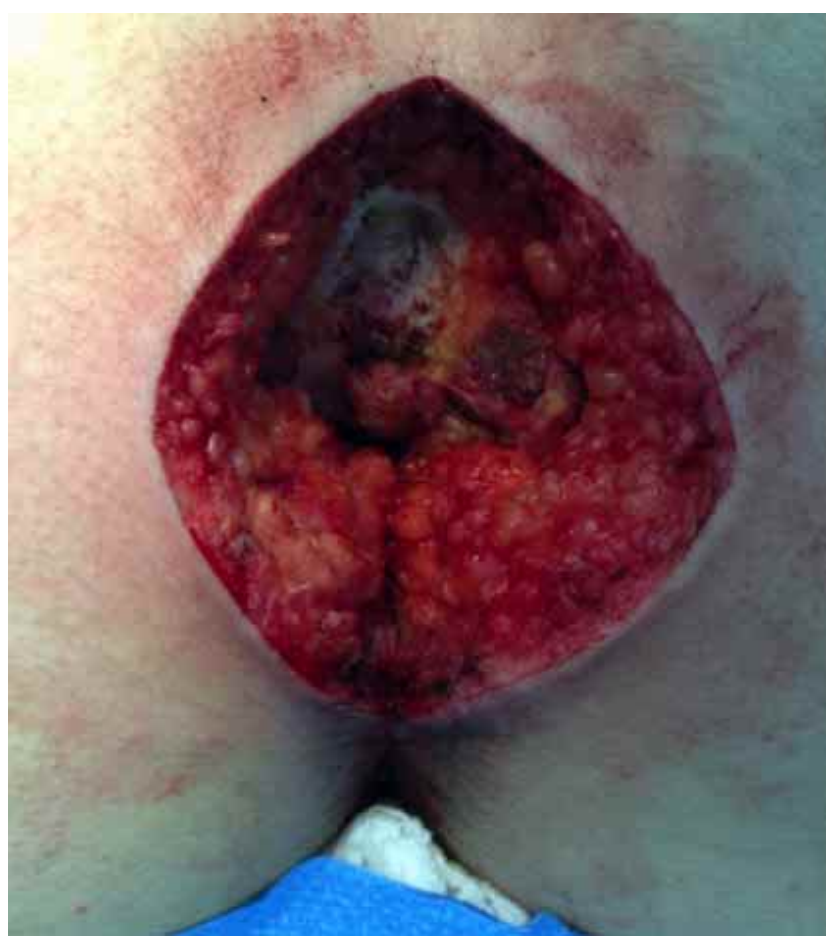

Fig. 3. Rhomboidal excision of the affected area until the presacral fascia. without tension and would result in a scar parallel to skin tension lines is preferred (Fig. 4).

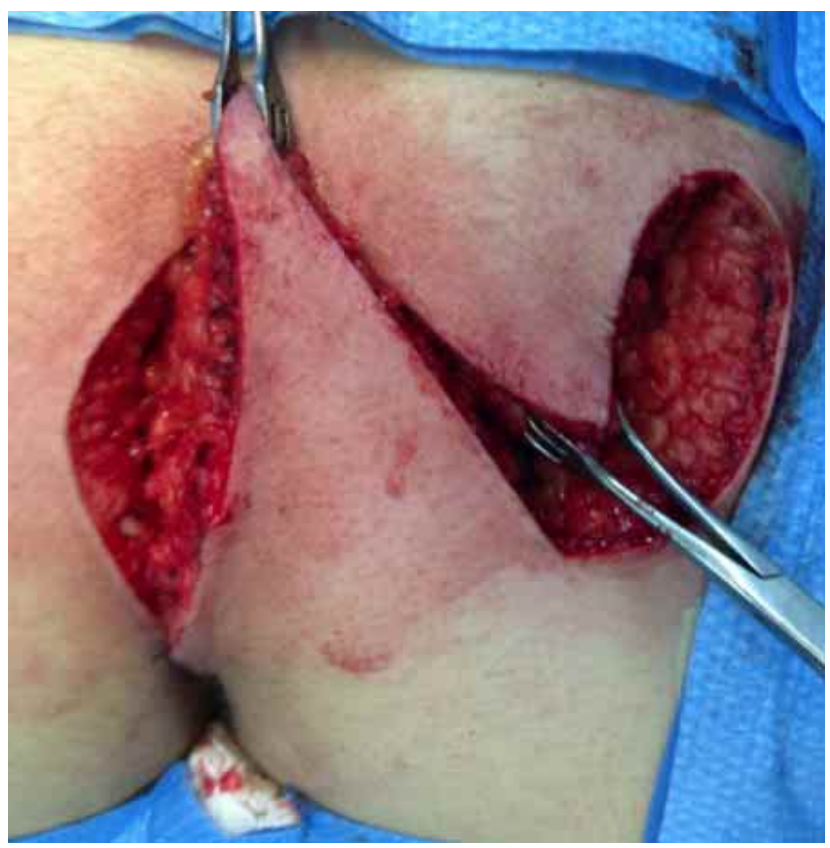

Fig. 4. Flap rotation.

Cover of the defect: After preparation, the flap was moved over the defect. Following careful hemostasis, the flap was prepared including the fascia of the gluteus maximus and moved onto the defect in the presacral fascia. Subcutaneous tissue of the flap was sutured to the gluteus maximus fascia with separate stitches of polyglactin-0. Subcutaneous cellular was sutured with polyglactin-00 and skin was closed with staples (Figs. 5 and 6). Finally, the resected specimen can be observed (Fig. 7).

\section{Risks of postoperative morbidity:}

1. Bleeding. To reduce it, any bleeding blood vessels would be cauterized throughout surgery to reduce the risk of a hematoma developing after the operation.

2. Wound infection. To diminish the risk of it, prophylaxis with intravenous antibiotics were given at the time of surgery.

3. Dehiscence. To decrease the probability of it, the suture lines must be free of tension, prevent seromas and hematomas, and the development of wound infection.

4. Pain. Is an uncommon problem, and could be avoided observing the measures described above to prevent seroma and hematoma formation, and wound infection.

5. Recurrence. This one is very complex because all known techniques had reported it (up to $10 \%$ according to different techniques). A refined and difficult surgical technique is essential to reduce the risks. Subsequently an exhaustive and long-term follow-up is very important to know the real numbers of recurrence. 


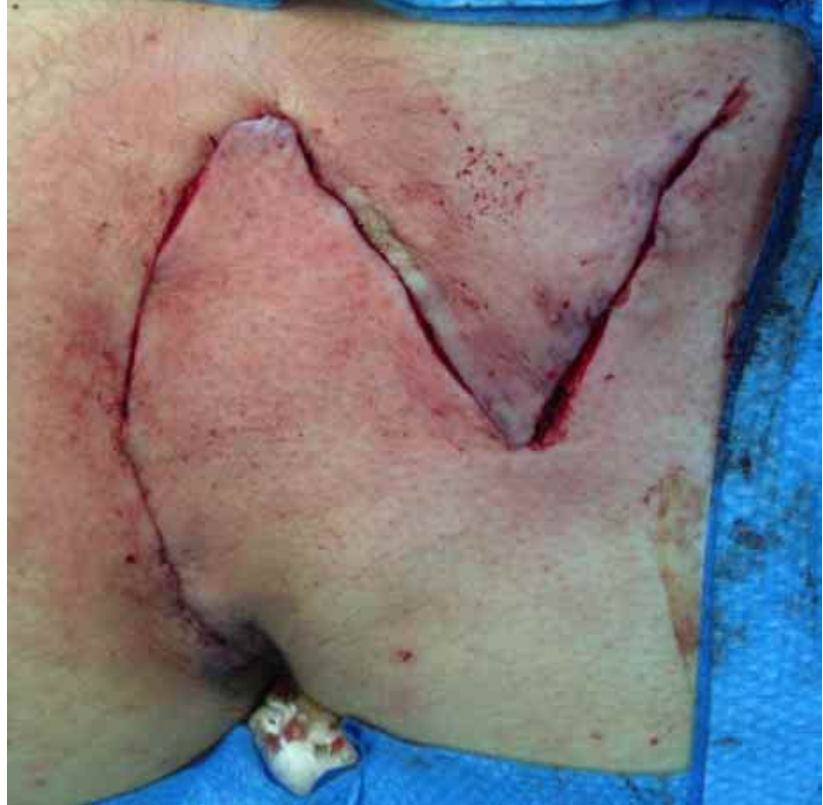

Fig. 5. Deep and superficial planes of the rhomboid flap sutured. Suction drain tube into deep space of the surgical area exteriorized by counter opening.

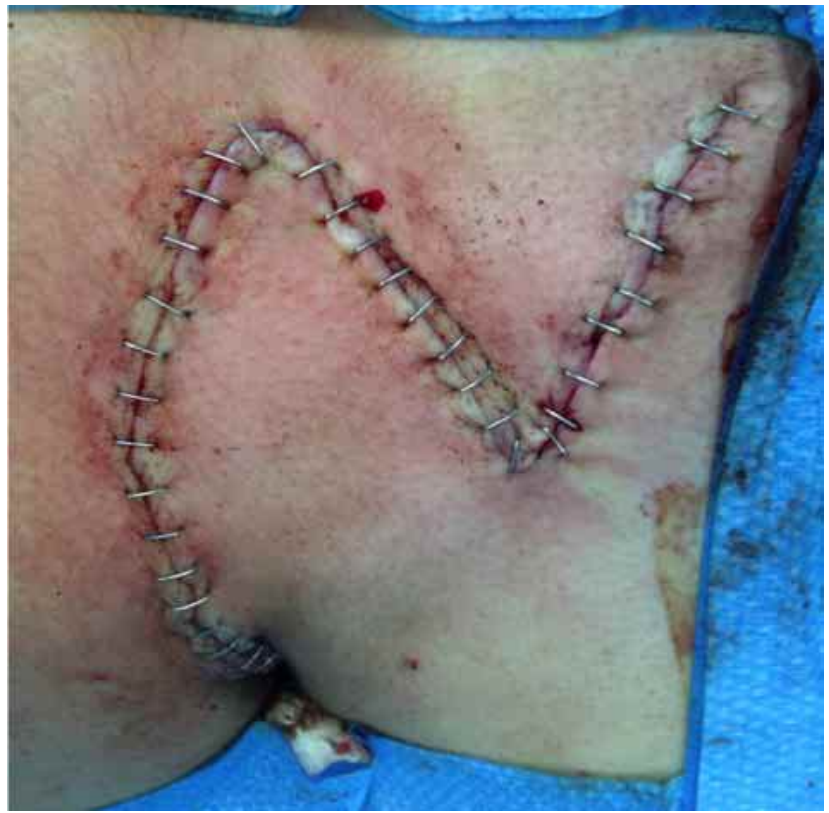

Fig. 6. Flap sutured and finalized surgery.

\section{DISCUSSION}

Pilonidal means "nest of hair" and derives from the Latin pilus (hair) and nidus (nest) (Manterola et al.; Steele et al., 2013; Sternberg, 2014), term used from 1830 onwards by Mayo (Koyfman, 2016). To this, was added "pilonidal cyst" proposed by Hodges in 1880 (Miller \& Harding, 2009).

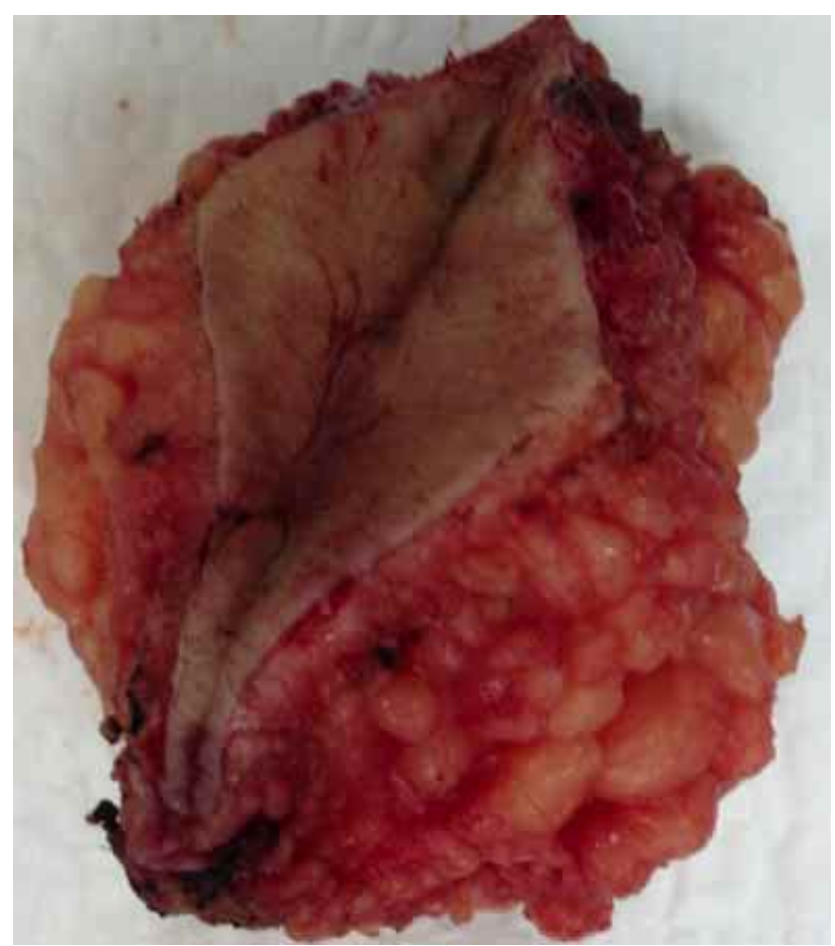

Fig. 7. Surgical specimen.

In relation to its surgical treatment, various alternatives have been described including open techniques (open resection), extensive resections (incision and curettage), marsupialization, excision and primary closure, resection and rotation flaps (z-plasty, Limberg technique, Dufourmentel triple L plasty, V-Y plasty, W-plasty, and modifications of some of these) (Petersen et al., 2002; Bannura, 2003; Al-Khamis et al.; Aydin et al.; Horwood et al.; Enriquez-Navascues et al.; Yabanoglu et al.), and the asymmetric resection (Karydakis technique) (Akinci et al., 2000; Bessa, 2007).

All of them have advantages and disadvantages regarding the development of complications, recovery time, recurrence rate, etc., the reason there is still no consensus on the ideal surgical alternative (Allen-Mersh, 1990; Akinci et al.; Petersen et al.; Hull \& Wu, 2002; Bannura; Al-Khamis et al.; Aydin et al.; Horwood et al.; Enriquez-Navascues et al.).

Nevertheless, it seems to us that the rhomboid flap is a good alternative for recurrent sacrococcygeal pilonidal sinus, especially for complex sinuses, and found it appropriate for cases where simpler techniques have failed. It permits early return to complete activity, does not require prolonged postoperative attention, and has very low recurrence rate and postoperative morbidity which may compensate the inconveniences related to an unfavorable cosmetic look. 
MANTEROLA, CARLOS; OTZEN, T. \& THE MINCIR GROUP. Técnica quirúrgica del colgajo de Dufourmentel para el tratamiento de la enfermedad pilonidal sacro-coccígea. Int. J. Morphol., 34(4):1207-1210, 2016.

RESUMEN: La enfermedad pilonidal sacrococcígea (EPS) es una entidad clínica crónica e infrecuente. Para su tratamiento se han descrito numerosas alternativas. Una de ellas es la exéresis de la zona afectada seguida de un cierre primario sin tensión, por medio de un colgajo romboidal descrito por Dufourmentel. El objetivo de este artículo es describir las fases más relevantes de la técnica. Se realiza una detallada explicación de los pasos clave para ejecutar la exéresis romboidal de la zona afectada, con la ulterior rotación de un colgajo de Dufourmentel para el tratamiento de la EPS. La exéresis romboidal de EPS seguida de la rotación de un colgajo de Dufourmentel constituye una alternativa a considerar en el tratamiento de la EPS.

PALABRAS CLAVE: Seno pilonidal; Quiste pilonidal; Cirugía del seno pilonidal; Cirugía del quiste pilonidal; Colgajo de Dufourmentel.

\section{REFERENCES}

Akinci, O. F.; Coskun, A. \& Uzunköy, A. Simple and effective surgical treatment of pilonidal sinus: asymmetric excision and primary closure using suction drain and subcuticular skin closure. Dis. Colon Rectum., 43(5):701-6, 2000.

Al-Khamis, A.; McCallum, I.; King, P. M. \& Bruce, J. Healing by primary versus secondary intention after surgical treatment for pilonidal sinus. Cochrane Database Syst Rev., (1):CD006213, 2010.

Allen-Mersh, T. G. Pilonidal sinus: finding the right track for treatment. Br. J. Surg., 77(2):123-32, 1990.

Aydin, O. E.; Tan, O.; Algan, S.; Kuduban, S. D.; Cinal, H. \& Barin, E. Z. Versatile use of rhomboid flaps for closure of skin defects. Eurasian J. Med., 43(1):1-8, 2011.

Bessa, S. S. Results of the lateral advancing flap operation (modified Karydakis procedure) for the management of pilonidal sinus disease. Dis. Colon Rectum, 50(11):1935-40, 2007.

Bannura, C. G. ¿Cuál es el tratamiento de elección de la enfermedad pilonidal sacrococcígea? Rev. Chil. Cir., 55(1):92-6, 2003.

Enriquez-Navascues, J. M.; Emparanza, J. I.; Alkorta, M. \& Placer, C. Meta-analysis of randomized controlled trials comparing different techniques with primary closure for chronic pilonidal sinus. Tech. Coloproctol., 18(10):863-72, 2014.

Hull, T. L. \& Wu, J. Pilonidal disease. Surg. Clin. North Am., 82(6):116985, 2002.

Horwood, J.; Hanratty, D.; Chandran, P. \& Billings, P. Primary closure or rhomboid excision and Limberg flap for the management of primary sacrococcygeal pilonidal disease? A meta-analysis of randomized controlled trials. Colorectal Dis., 14(2):143-51, 2012.

Koyfman, A. Pilonidal Cyst and Sinus. Medscape, 2016. Available from: http://emedicine.medscape.com/article/788127-overview

McCallum, I. J.; King, P. M. \& Bruce, J. Healing by primary closure versus open healing after surgery for pilonidal sinus: systematic review and meta-analysis. B. M. J., 336(7649):868-71, 2008.

Miller, D. \& Harding, K. Pilonidal Sinus Disease. World Wide Wounds, 2009. Available from: http://www.worldwidewounds.com/2003/ december/Miller/Pilonidal-Sinus.html
Manterola, C.; Barroso, M.; Araya, J. C. \& Fonseca, L. Pilonidal disease: 25 cases treated by the Dufourmentel technique. Dis. Colon Rectum, 34(8):649-52, 1991.

Petersen, S.; Koch, R.; Stelzner S.; Wendlant, T. P. \& Ludwig, K. Primary closure techniques in chronic pilonidal sinus: a survey of the results of different surgical approaches. Dis. Colon Rectum, 45(11):145867,2002

Steele, S. R.; Perry, W. B.; Mills, S.; Buie, W. D. \& Standards Practice Task Force of the American Society of Colon and Rectal Surgeons. Practice parameters for the management of pilonidal disease. Dis. Colon Rectum, 56(9):1021-7, 2013.

Sternberg, J. A. The Management of Pilonidal Disease. In: Cameron, J. L. \& Cameron, A. M. (Eds.). Current Surgical Therapy. $11^{\text {th }}$ ed. Philadelphia, Saunders, 2014. pp.293-301.

Sondenaa, K.; Andersen, E.; Nesvik, I. \& Søreide, J. A. Patient characteristics and symptoms in chronic pilonidal sinus disease. Int. J. Colorectal Dis., 10(1):39-42, 1995.

Yabanoglu, H.; Karagulle, E.; Belli, S. \& Turk, E. Results of modified Dufourmentel rhomboid flap in patients with extensive Sacrococcygeal pilonidal disease. Acta Chir. Belg., 114(1):52-7, 2014.

\author{
Correspondence to: \\ Dr. Carlos Manterola, MD, Ph.D. \\ Department of Surgery and CEMyQ \\ Universidad de La Frontera \\ Temuco \\ CHILE
}

E-mail: carlos.manterola@ufrontera.cl

Received: 20-03-2016

Accepted: 16-09-2016 